\title{
The uptake of ${ }^{3} \mathrm{H}$-labelled monodeoxyfluoro-myo-inositols into thymocytes and their incorporation into phospholipid in permeabilized cells
}

\author{
John OFFER, James C. METCALFE* and Gerry A. SMITH \\ Department of Biochemistry, University of Cambridge, Tennis Court Road, Cambridge CB2 1QW, U.K.
}

Monodeoxyfluoro-myo-inositols were applied to electropermeabilized and intact thymocyte preparations to study their metabolism and uptake in order to investigate their suitability as potential inhibitors of phosphoinositide-mediated cellular responses. Only three of the monodeoxyfluoro-myo-inositols were incorporated into the phospholipids of thymocytes: 1D-3deoxy-3-fluoro-myo-inositol, 5-deoxy-5-fluoro-myo-inositol and 1D-6-deoxy-6-fluoro-myo-inositol, all of which were weaker substrates for phosphatidylinositol synthase than was myo-inositol. The 3-, 5- and 6-fluoro analogues also behaved as competitive inhibitors, with $K_{1}$ values of $350 \pm 5 \mu \mathrm{M}, 350 \pm 5 \mu \mathrm{M}$ and $2.9 \pm 2 \mathrm{mM}$ respectively, compared with a $K_{\mathrm{m}}$ for $m y o$-inositol of $31 \pm 4 \mu \mathrm{M}$. When incubated with electropermeabilized thymocyte preparations, these three analogues of myo-inositol all formed phospholipids with chromatographic properties which corresponded to those of substituted phosphatidylinositol and phosphatidylinositol monophosphate. The uptake of myoinositol and of the monodeoxyfluoro-myo-inositols into intact thymocytes was studied by a dual-label technique. All the monodeoxyfluoro-myo-inositols were taken up to some extent, but only 2-deoxy-2-fluoro-myo-inositol and 1D-3-deoxy-3-fluoromyo-inositol were actively concentrated. The monodeoxyfluoromyo-inositols were also assayed for their ability to inhibit the uptake of myo-inositol into cells. Both 2-deoxy-2-fluoro-myoinositol and 1D-3-deoxy-3-fluoro-myo-inositol were effective inhibitors of myo-inositol uptake. Furthermore, 1D-1-deoxy-1fluoro-myo-inositol, which was not taken up actively, was an effective inhibitor of myo-inositol uptake. The three effective inhibitors all showed $K_{\mathrm{i}}$ values of $\sim 150 \mu \mathrm{M}$, close to the apparent $K_{\mathrm{m}}$ for inositol uptake of $180 \mu \mathrm{M}$, and the 4-, 5- and 6-fluoro analogues had $K_{\mathrm{i}}$ values in excess of $10 \mathrm{mM}$.

\section{INTRODUCTION}

The hydrolysis of a membrane lipid, phosphatidylinositol 4,5bisphosphate $\left[\mathrm{PtdIns}(4,5) P_{2}\right]$, is one of the earliest responses to the activation of cellular receptors coupled to the release of $\mathrm{Ca}^{2+}$ from intracellular sites. The release of $\mathrm{Ca}^{2+}$ is mediated by inositol 1,4,5-trisphosphate, which is produced by the phospholipase C-catalysed hydrolysis of $\operatorname{PtdIns}(4,5) P_{2}$. This hydrolysis also generates diacylglycerol, which is an activator of protein kinase $C$. The precise role of these events in many cellular responses remains to be defined. For example, many growth factor and mitogen receptors are coupled to $\operatorname{PtdIns}(4,5) P_{2}$ breakdown (Whitman and Cantley, 1988), but there is conflicting evidence on whether the response is essential for proliferation. In lymphocytes with mutant $\beta-\mathrm{T}$ cell receptors, the normal responses to phytohaemagglutinin or anti-CD3 antibody, including PtdIns $(4,5) P_{2}$ breakdown and cell growth, are absent, but these functions are restored on transfection with $T_{1} \beta$ component cDNA (Alcover et al., 1988). Furthermore, when the human muscarinic subtype-1 receptor HM1, which elicits phosphoinositide metabolism in neuronal cells, is expressed in a $\mathrm{T}$ cell clone, stimulation of the HM1 receptors activates phosphoinositide turnover and cell growth (Desai et al., 1990). In contrast, when the $T$ cell receptor complex is restored to a mutant hybridoma, which lacks the receptor $\alpha$ and $\beta$ components, the interleukin-2 (IL-2) production response to antibody is restored but no increase in PtdIns $(4,5) \boldsymbol{P}_{\mathbf{2}}$ hydrolysis is detectable (Sussman et al., 1988).

To determine the functional responses coupled to $\operatorname{PtdIns}(4,5) P_{2}$ hydrolysis in response to growth factors and other types of agonist, it would be useful to have specific inhibitors of this hydrolysis. However, no specific chemical inhibitors of either PtdIns $(4,5) P_{2}$ formation or hydrolysis have been developed. The six monofluorinated analogues of myo-inositol, in which a single hydroxyl group is replaced by a fluorine, were therefore synthesized as potential inhibitors of $\operatorname{PtdIns}(4,5) P_{2}$ formation and hydrolysis. The rationale was that the monodeoxyfluoromyo-inositols might be taken up into cells by the same uptake process as myo-inositol, and either be incorporated into phospholipid as substituted PtdIns or polyphosphoinositide, or prevent their formation, depending on the position of the fluorine substituent. To evaluate the monodeoxyfluoro-myo-inositols as potential inhibitors of phosphoinositide metabolism, their incorporation into phospholipid in electroporated mouse thymocytes and their uptake into the intact cells have been characterized. The ${ }^{3} \mathrm{H}$-labelled monodeoxyfluoro-myo-inositols, prepared by synthetic procedures that we have recently described (Offer et al., 1992), were used for both types of assay.

\section{MATERIALS AND METHODS}

\section{Monodeoxyfluoro-myo-inositols}

The unlabelled and ${ }^{3} \mathrm{H}$-labelled monodeoxyfluoro-myo-inositols were prepared, with at least the same purity, as described previously (Offer et al., 1992). myo-[2- $\left.{ }^{3} \mathrm{H}\right] \mathrm{Inositol}(17.6 \mathrm{Ci} /$ mmol), phosphatidyl-myo- $\left[2-{ }^{3} \mathrm{H}\right]$ inositol $(10 \mathrm{Ci} / \mathrm{mmol})$, phosphatidyl-myo-[2- $\left.{ }^{3} \mathrm{H}\right]$ inositol 4,5 -bisphosphate $\quad(1.0 \mathrm{Ci} / \mathrm{mmol})$, phosphatidyl-myo- $\left[2-{ }^{3} \mathrm{H}\right]$ inositol 4 -phosphate $(1.0 \mathrm{Ci} / \mathrm{mmol})$ and $\left[2-{ }^{14} \mathrm{C}\right]$ ethanolamine $(50 \mathrm{mCi} / \mathrm{mmol})$ were supplied by Amersham International. Scintillation counting was performed in Optiphase II (LKB) with an external standard quench correction and spill-over correction for dual-label $\left({ }^{3} \mathrm{H}\right.$ and $\left.{ }^{14} \mathrm{C}\right)$ experiments. 
Basal diploid Eagle's medium (inositol-free) was from Gibco; all other chemicals were AnalaR grade. Incubations of cells, intact or permeabilized, were carried out at $37^{\circ} \mathrm{C}$ in air $/ \mathrm{CO}_{2}(19: 1)$.

\section{Thymocyte preparation and electroporation}

Thymuses were isolated from 4-6-week-old mice. The thymuses were teased into myo-inositol-free medium supplemented with $\mathrm{NaHCO}_{3}(24 \mathrm{mM})$ and Hepes $(22 \mathrm{mM})$ at $\mathrm{pH}$ 7.2. Connective tissue was pelleted by leaving the suspension to settle before the supernatant was decanted and washed once by centrifugation $(3 \mathrm{~min}, 250 \mathrm{~g}$ ). The cell concentration was determined using a haemocytometer and the viability of the cells was assayed by exclusion of $0.05 \%$ sodium eosin for $10 \mathrm{~min}$. The thymocytes were resuspended at the required cell concentration $\left(4 \times 10^{8}\right.$ cells $/ \mathrm{ml}$, unless otherwise stated) in myo-inositol-free medium.

For electroporation, the suspension medium was supplemented with $\mathrm{Mg}^{2+}(30 \mathrm{mM})$, EGTA $(3 \mathrm{mM})$, potassium ATP $(12 \mathrm{mM})$ and CTP $(2 \mathrm{mM})$ at $\mathrm{pH}$ 7.2. The cells were equilibrated for $15 \mathrm{~min}$ at $37^{\circ} \mathrm{C}$ before a $1.0 \mathrm{ml}$ aliquot of cell suspension was added to an electroporation cuvette $(1.0 \mathrm{~cm} \times 1.0 \mathrm{~cm} \times 2.5 \mathrm{~cm})$ and pulsed with five cycles of $1.5 \mathrm{kV} / 1.0 \mu \mathrm{F}$ at $30 \mathrm{~s}$ intervals using a Bio-Rad gene pulser. The efficiency of electroporation was monitored by the ability of the electroporated cells to take up $0.05 \%$ sodium eosin or Trypan Blue in $10 \mathrm{~min}$. Under the electroporation conditions defined above, more than $95 \%$ of the cells were permeabilized and no resealing of the cells was observed over the time course of the experiments.

\section{Measurement of myo-inositol concentration}

Inositol concentrations were assayed by a modification of the method of Maslanski and Busa (1990). Samples $(1.0 \mathrm{ml})$ were heated to $100^{\circ} \mathrm{C}$ for $5 \mathrm{~min}$, cooled to room temperature, clarified by centrifugation $(15000 \mathrm{~g}, 5 \mathrm{~min})$, passed through a short Pasteur pipette containing mixed strong cation- and anionexchange resin (Dowex MR-3), washed through with water and the eluate evaporated to dryness. Samples were then added to a fluorimeter cuvette containing $\mathrm{NAD}^{+}(1.0 \mathrm{mM})$ and freshly purified resazurin $(10 \mu \mathrm{M})$ and diaphorase (Sigma) $(2$ units $/ \mathrm{ml})$ in phosphate buffer $(100 \mathrm{mM})$ at a $\mathrm{pH}(7.2)$ at which the reaction rate is limited onty by the myo-inositol concentration. After equilibration at $37^{\circ} \mathrm{C}$ for $5 \mathrm{~min}$, the coupled enzyme reaction was started by the addition of inositol dehydrogenase $(0.125 \mathrm{unit} / \mathrm{ml})$ and the rate of production of resorufin was followed by fluorimetry at excitation and emission wavelengths of 565 and $585 \mathrm{~nm}$ respectively. Standard curves, linear in the measuring range, were constructed by addition of myo-inositol in place of the sample.

\section{myo- $\left[2-{ }^{3} \mathrm{H}\right]$ Inositol and monodeoxyfluoro-myo- $\left[2-{ }^{3} \mathrm{H}\right]$ Inositol incorporation into phospholipid}

The electroporated thymocytes $(1.0 \mathrm{ml})$ were poured on to $35 \mathrm{~mm}$ dishes (ICN Flow) and incubated in a gassed incubator (air $/ \mathrm{CO}_{2}$, $19: 1,37^{\circ} \mathrm{C}$ ), in the presence of $5.0 \mu \mathrm{Ci}$ of $m y o$-inositol or $5.0 \mu \mathrm{Ci}$ of monodeoxyfluoro-myo- $\left[2-{ }^{3} \mathrm{H}\right]$ inositol at the required concentration added at $0 \mathrm{~h}$. Incubations were terminated by vortexmixing the samples with $3.0 \mathrm{ml}$ of chloroform/methanol $(1: 2$, $\mathrm{v} / \mathrm{v}$ ) and phospholipid extractions were performed as described in Stein and Smith (1982). The mixture was partitioned into upper and lower phases by the addition of $1.5 \mathrm{ml}$ of $100 \mathrm{mM}$ $\mathrm{NaCl}$ containing $2.0 \mathrm{mM}$ myo-inositol, and a further $1.0 \mathrm{ml}$ of chloroform was added. The sample was briefly centrifuged to separate the two phases, the lower phase was removed and washed with $2.0 \mathrm{ml}$ of chloroform $/ 100 \mathrm{mM} \mathrm{NaCl}$ containing $2.0 \mathrm{mM}$ myo-inositol $(1: 1, \mathrm{v} / \mathrm{v})$ by vortex-mixing and centrifugation. The lower phase was dried under a stream of nitrogen and ${ }^{3} \mathrm{H}$ label was assayed by liquid scintillation counting.

To measure the apparent inhibitory constants of monodeoxyfluoro-myo-inositols for the incorporation of myo-inositol into phospholipid, aliquots $(100 \mu \mathrm{l})$ of electroporated thymocytes $\left(4 \times 10^{8}\right.$ cells $\left./ \mathrm{ml}\right)$ were incubated in glass test tubes with $2.0 \mu \mathrm{Ci}$ of $m y o-\left[2-{ }^{3} \mathrm{H}\right]$ inositol and unlabelled monodeoxyfluoro-myoinositol at known concentrations for $0.5 \mathrm{~h}$ at $37^{\circ} \mathrm{C}$. The incubation was terminated by the addition of $3.0 \mathrm{ml}$ of chloroform/methanol $(1: 2, \mathrm{v} / \mathrm{v})$, and samples were treated as above to assay for ${ }^{3} \mathrm{H}$ incorporation into phospholipid.

\section{Analysis of $\left[{ }^{3} \mathrm{H}\right]$ phosphoinositides and modlfied [ $\left.{ }^{3} \mathrm{H}\right]$ phosphoinositides}

Aliquots $(0.5 \mathrm{ml})$ of the electroporated thymocyte suspension were incubated in the presence of $m y o-\left[2-{ }^{3} \mathrm{H}\right]$ inositol or monodeoxyfluoro-myo- $\left[2-^{3} \mathrm{H}\right]$ inositol at $37^{\circ} \mathrm{C}$. Incubations were terminated by resuspending the cells in $5.0 \mathrm{ml}$ of chloroform/ methanol $(1: 2, \mathrm{v} / \mathrm{v})$ with vortex-mixing, and the extract was partitioned into upper and lower layers by the addition of $1.9 \mathrm{ml}$ of $100 \mathrm{mM} \mathrm{NaCl}$ containing $2.0 \mathrm{mM}$ myo-inositol and then $2.0 \mathrm{ml}$ of chloroform, followed by vortex-mixing. The lower layer was removed and dried under a stream of nitrogen. To the upper layer was added $5.0 \mathrm{ml}$ of chloroform/methanol $(1: 2, \mathrm{v} / \mathrm{v})$ containing $0.25 \%$ (v/v) conc. $\mathrm{HCl}$ followed by vortex-mixing. The extract was partitioned into upper and lower phases by the addition of $3.4 \mathrm{ml}$ of $100 \mathrm{mM} \mathrm{NaCl}$ containing $2.0 \mathrm{mM}$ myoinositol. The lower phase was removed, neutralized by the addition of a drop of $4 \mathrm{M} \mathrm{NH}_{4} \mathrm{OH}$, and the chloroform was evaporated under a stream of nitrogen. The products from the neutral and acid extractions were dissolved in methanol/ chloroform (3:7, v/v) and were chromatographed either combined or separately by t.l.c performed on silica-gel-precoated glass sheets (Merck plates $60 \mathrm{~F}_{254}$ ) soaked in a solution of $1.3 \%$ potassium oxalate ( $\mathrm{pH} 7.5)$ and $1 \mathrm{mM}$ EGTA in water/methanol $(3: 2, v / v)$, and then air-dried. The silica gel sheets were activated by heating at $80^{\circ} \mathrm{C}$ for $1 \mathrm{~h}$ in a vacuum oven and cooled to room temperature before use. The eluant for chromatography of the phosphoinositides was chloroform/ methanol/water $/ \mathrm{NH}_{4} \mathrm{OH}$ (45:35:7:2, by vol.) and plates were dried and scanned for radioactivity using a Berthold automatic t.l.c. linear analyser. The ${ }^{3} \mathrm{H}$ label was measured with $0.2 \%$ efficiency and single tracks were counted for $2 \mathrm{~h}$. The positions of the phosphoinositides were located by the use of parallel tracks of phosphatidyl-myo- $\left[2-{ }^{3} \mathrm{H}\right]$ inositol, phosphatidyl$m y o-\left[2-{ }^{3} \mathrm{H}\right]$ inositol $4,5-b i s p h o s p h a t e$ and phosphatidyl-myo- $[2-$ $\left.{ }^{3} \mathrm{H}\right]$ inositol 4-phosphate.

\section{Uptake of myo-[2-3 $\left.{ }^{3}\right]$ inositol and monodeoxyfluoro-myo- $\left[2-{ }^{3} \mathrm{H}\right]$ inositol into intact thymocytes}

Thymocytes $(1.0 \mathrm{ml})$ were suspended at $10^{8}$ cells $/ \mathrm{ml}$ in myoinositol-free medium. The cells were left after preparation for $1 \mathrm{~h}$ in a culture dish ( $35 \mathrm{~mm}$ diameter) in an incubator until the intracellular ATP concentrations had reached a maximum constant level of $4.6 \mathrm{mM}$ [assayed by the method of Stanley and Williams (1969)]. A dual-label technique was used for the uptake experiments, to correct for any variability in cell number when using small volumes of cells at high density. Thymocytes at $10^{6} / \mathrm{ml}(2.0 \mathrm{ml})$ were treated with $\left[{ }^{14} \mathrm{C}\right]$ ethanolamine at $15 \mu \mathrm{Ci} / \mathrm{ml}$ for $1 \mathrm{~h}$ at $37^{\circ} \mathrm{C}$ before centrifugation, washed three times with myo-inositol-free medium to remove excess $\left[{ }^{14} \mathrm{C}\right]$ ethanolamine 
and resuspended in $1.0 \mathrm{ml}$ of myo-inositol-free medium. An aliquot of the labelled cells was added to the unlabelled cells to give approx. 1000 c.p.m. $/ 10^{7}$ cells. The thymocytes were diluted with myo-inositol-free medium to a density of $5 \times 10^{7} \mathrm{cells} / \mathrm{ml}$ (the maximum density at which the cells did not become anaerobic under the incubation conditions used, as assayed at ATP content). Aliquots $(220 \mu \mathrm{l})$ of the cell suspension were added to the wells of a 48-well culture plate (Costar) pre-loaded with myo-[2$\left.{ }^{3} \mathrm{H}\right]$ inositol or monodeoxyfluoro-myo- $\left[2-{ }^{3} \mathrm{H}\right]$ inositol plus the required concentration of unlabelled myo-inositol or monodeoxyfluoro-myo-inositol, and incubated at $37^{\circ} \mathrm{C}$ in a gassed incubator.

Cells were resuspended using a wide-orifice pipette and aliquots $(200 \mu \mathrm{l})$ of the sample were placed gently on the top of a pre-spun gradient of dibutyl phthalate (pre-washed three times with $0.2 \mathrm{ml}$ of medium) and Ficoll/medium $(6 \%, \mathrm{w} / \mathrm{v} ; 0.5 \mathrm{ml})$ at $0{ }^{\circ} \mathrm{C}$, and centrifuged $(15000 \mathrm{~g}, 90 \mathrm{~s})$. The contents of the Microfuge tubes were frozen in solid $\mathrm{CO}_{2}$ and the tip containing the cells was cut from the tube, vortex-mixed with scintillation fluid and assayed for ${ }^{3} \mathrm{H}$ and ${ }^{14} \mathrm{C}$ by liquid scintillation counting. The ${ }^{3} \mathrm{H}$ counts gave the amount of myo-inositol or monodeoxyfluoro-myoinositol uptake into the cells, and the ${ }^{14} \mathrm{C}$ counts were used to correct for small variations $( \pm 15 \%)$ in the number of cells.

\section{RESULTS}

Preliminary electroporation experiments were performed to maximize the incorporation of radioactivity into the lipids, especially for the weaker substrates. Firstly, the cell density was varied in the presence of supra-maximal concentrations of inositol and ATP to ascertain the highest cell density at which the initial incorporation rate was proportional to the number of cells used. Linearity was obtained at cell concentrations up to approx. $10^{\%} / \mathrm{ml}$. To maintain the highest levels of PtdIns and polyphosphoinositides over the longest incubations used $(8 \mathrm{~h})$ for the permeabilized cells at a cell density of $3.5 \times 10^{8} \mathrm{cells} / \mathrm{ml}$, concentrations of $2 \mathrm{mM}$ CTP and $12 \mathrm{mM}$ ATP were required.

\section{Incorporation of myo-[2- $\left.{ }^{3} \mathrm{H}\right]$ Inositol and monodeoxyfluoro-myo- [2- ${ }^{3}$ H] inositols into the phospholipids of electroporated thymocytes}

The concentration of endogenous myo-inositol in thymocytes, assayed using myo-inositol dehydrogenase, was $840 \pm 50 \mu \mathrm{M}$ $(n=3)$. The time course of incorporation of added myo-[2- $\left.{ }^{3} \mathrm{H}\right]$ inositol $(5 \mu \mathrm{Ci} / 2.5 \mu \mathrm{M})$ into the phospholipid of electroporated cells $\left(4 \times 10^{8} \mathrm{cells} / \mathrm{ml}\right)$ is shown in Figure 1 . After the first hour, $70 \%$ of the available ${ }^{3} \mathrm{H}$ label was incorporated, increasing to $85 \%$ by $2 \mathrm{~h}$, after which the total label incorporated into phospholipid declined. The apparent $K_{\mathrm{m}}$ for myo-inositol incorporation, estimated from the concentration-dependence of the rate of incorporation of myo- $\left[2-{ }^{3} \mathrm{H}\right]$ inositol into phospholipid measured $0.5 \mathrm{~h}$ after permeabilization, was $31 \pm 4 \mu \mathrm{M}$ (Figure 2).

Three of the monodeoxyfluoro-myo- $\left[2-{ }^{3} \mathrm{H}\right]$ inositols showed incorporation into phospholipid, but at a slower rate and to a lower level than for $m y o-\left[2-{ }^{3} \mathrm{H}\right]$ inositol (Figure 1). The others (1D-1-deoxy-1-fluoro-myo-[2- $\left.{ }^{3} \mathrm{H}\right]$ inositol, 2-deoxy-2-fluoromyo-[2- $\left.{ }^{3} \mathrm{H}\right]$ inositol and $1 \mathrm{D}-4-$ deoxy-4-fluoro-myo- $\left[2-{ }^{3} \mathrm{H}\right]$ inositol) showed no significant incorporation into phospholipid above background c.p.m. At a concentration of $3.5 \times 10^{8}$ electroporated cells $/ \mathrm{ml}$, the $m y o$-inositol concentration in the cell suspension was $35 \mu \mathrm{M}$ (released from the cells on electroporation). The myoinositol concentration of $35 \mu \mathrm{M}$ was approximately equivalent to the apparent $K_{\mathrm{m}}$ for the incorporation of myo-inositol into phospholipid, implying that half of the total available synthase enzyme was bound to myo-inositol and was not available. Hence, assuming competitive kinetics, the initial rates of incorporation of the analogues, at concentrations well below their $K_{d}$ values, were approximately half the values they would have been if no endogenous myo-inositol had been present. If the added myo-

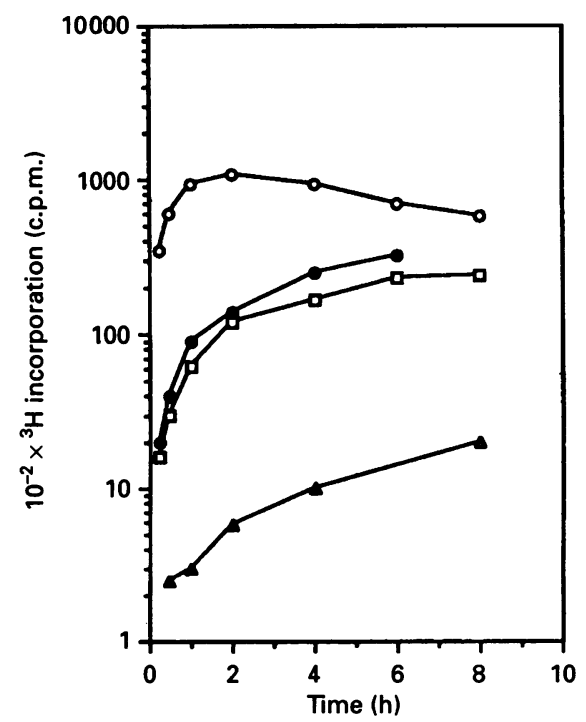

Figure 1 Time course of incorporation of myo-[2-3 $\mathrm{H}]$ inositol and monodeoxyfiluoro-myo-[2-3 $\left.{ }^{3}\right]$ inositols Into phospholipid of permeabilized cells

Aliquots $(1.0 \mathrm{ml})$ of thymocytes $\left(3.5 \times 10^{8}\right.$ cells $\left./ \mathrm{ml}\right)$ were electropermeabilized at $t=0$ at $1.8 \mathrm{kV}$ and $1.0 \mu \mathrm{F}$ in the presence of $5 \mu \mathrm{Ci}$ myo-inositol or analogue at a concentration of $2.5 \mu \mathrm{M}$. Aliquots $(50 \mu \mathrm{l})$ were extracted and assayed for ${ }^{3} \mathrm{H}$ incorporation into phospholipid as described in the Materials and methods section. O, myo- $\left[2-{ }^{3} \mathrm{H}\right]$ Inositol; O, 10-3-deoxy-3fluoro-myo-[2- $\left.{ }^{3} \mathrm{H}\right]$ inositol; $\square, 5$-deoxy-5-fluoro-myo-[2- $\left.{ }^{3} \mathrm{H}\right]$ inositol; $\triangle$, 10-6-deoxy-6-fluoromyo- $\left[2{ }^{3} \mathrm{H}\right]$ inositol. Each point is the mean of duplicates. Data are from a single experiment typical of three.

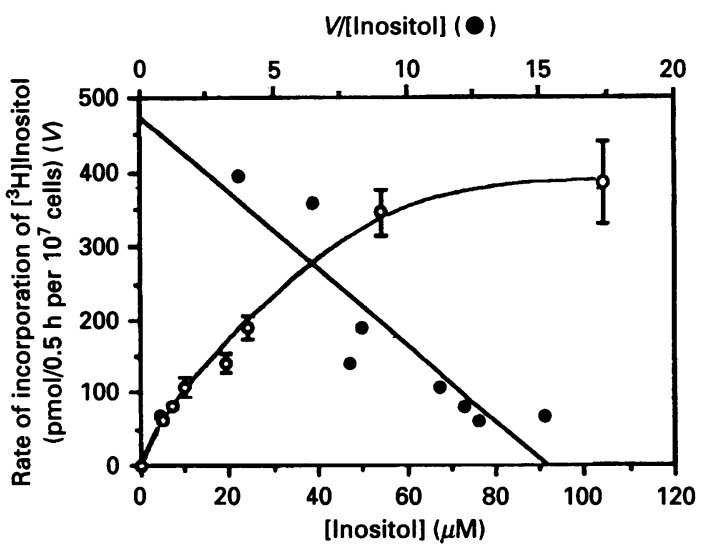

Figure 2 Concentration-dependence of myo-inositol incorporation into phospholipid

Aliquots $(100 \mu l)$ of electroporated thymocytes $\left(3.5 \times 10^{7}\right.$ cells $\left./ \mathrm{ml}\right)$ were incubated in the presence of myo-[2- $\left.{ }^{3} \mathrm{H}\right]$ inositol for $0.5 \mathrm{~h}$ at the concentrations of myo-inositol indicated (these include the endogenous myo-inositol). The ${ }^{3} \mathrm{H}$ incorporation into phospholipids was quantified as described in the Materials and methods section. Incorporation rates, which were calculated from the ${ }^{3} \mathrm{H}$ incorporated into phospholipid and the known specific radioactivity of myo-inositol in each sample, were expressed as pmol of myo-inositol incorporated $/ 0.5 \mathrm{~h}$ per $10^{7}$ cells. The data were replotted according to the method of Eadie and Hotstee to obtain the apparent $K_{\mathrm{m}}$ for incorporation of myo-inositol into phospholipid. The slope was fitted using a least-squares procedure. Each point is the mean \pm S.E.M. for triplicate measurements. The data are from a single experiment typical of three. 

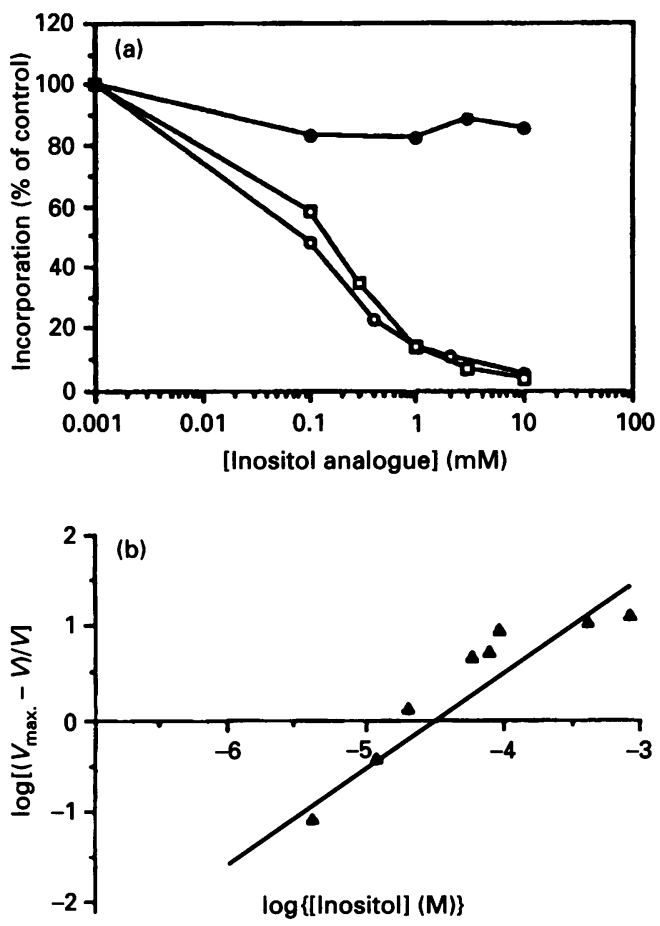

Figure 3 Characterization of the inhibition of myo-inositol incorporation into phospholipid

(a) Aliquots $(10 \mu l)$ of electroporated thymocytes $\left(3.5 \times 10^{8} \mathrm{cell} / \mathrm{s} / \mathrm{ml}\right)$ were incubated in a glass test tube at $37^{\circ} \mathrm{C}$ in the presence of myo- $\left[2{ }^{3} \mathrm{H}\right]$ inositol $(1 \mu \mathrm{Ci})$ at a concentration of $35 \mu \mathrm{M}$ myo-inositol (including endogenous myo-inositol) for $0.5 \mathrm{~h}$ with the indicated concentrations of: O, 10-3-deoxy-3-fluoro-myo-inositol; $\square$, 5-deoxy-5-fluoro-myo-inositol; O, 10-6-deoxy-6fluoro-myo-inositol. Samples were assayed for ${ }^{3} \mathrm{H}$ incorporation into phospholipid, as described in the Materials and methods section. (b) Aliquots $(100 \mu \mathrm{l})$ of electroporated thymocytes $\left(3.5 \times 10^{7} \mathrm{cells} / \mathrm{ml}\right)$ were incubated in a glass test tube at $37^{\circ} \mathrm{C}$ in the presence of 5 -deoxy5-fluoro-myo- $\left[2 \cdot{ }^{3} \mathrm{H}\right]$ inositol and unlabelled myo-inositol at the concentrations indicated (including endogenous myo-inositol). Samples were terminated and assayed as above. $V$ is the rate of ${ }^{3} \mathrm{H}$ incorporation into phospholipid at the indicated concentrations of myo-inositol. The slope was fitted using a least-squares procedure.

$\left[2-{ }^{3} \mathrm{H}\right]$ inositol was viewed as competing against the much higher concentration of endogenous myo-inositol (i.e. as for the analogues), the incorporation of $m y o-\left[2-{ }^{3} \mathrm{H}\right]$ inositol could be compared directly with the incorporation of the myo-inositol analogues. The data showed that the initial rates of incorporation of 1D-3-deoxy-3-fluoro-myo-[2- $\left.{ }^{3} \mathrm{H}\right]$ inositol and 5-deoxy-5-fluoro$m y o-\left[2-{ }^{3} \mathrm{H}\right]$ inositol were approximately 10 -fold lower than the lower initial rate of incorporation of myo-inositol, and the rate for 1D-6-deoxy-6-fluoro-myo-[2- $\left.{ }^{3} \mathrm{H}\right]$ inositol was approx. 200 -fold lower.

The dose-dependent inhibition of the incorporation of myo-[2${ }^{3} \mathrm{H}$ ]inositol into phospholipid by the three monodeoxyfluoromyo-inositols incorporated into phospholipid is shown in Figure 3(a). The apparent inhibitory constant was determined for each of the three compounds by a Dixon plot, which gave values of $350 \pm 50 \mu \mathrm{M}$ for 5-deoxy-5-fluoro-myo-inositol and 1D-3-deoxy3-fluoro-myo-inositol and a value of $2.9 \pm 0.2 \mathrm{mM}$ for $1 \mathrm{D}-6-$ deoxy-6-fluoro-myo-inositol. The remaining monodeoxyfluoromyo-inositols showed no inhibition at concentrations up to $10 \mathrm{mM}$. The internal consistency of these data was tested by back-titrating the incorporation of 5-deoxy-5-fluoro-myo$\left[2-{ }^{3} \mathrm{H}\right]$ inositol with unlabelled $m y o$-inositol. The concentration of 5-deoxy-5-fluoro-myo-inositol used was well below its apparent $K_{\mathrm{i}}$ for the synthase to ensure a small ratio of pseudo-substrate-

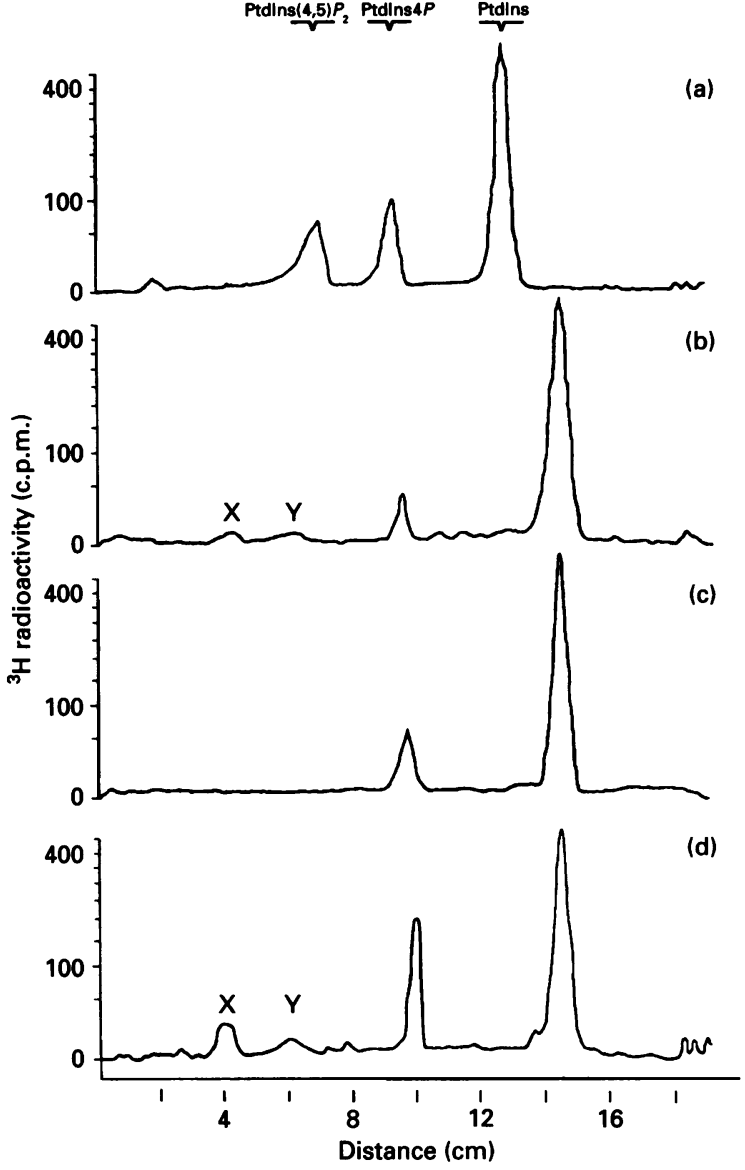

Figure 4 Separation of $\left[{ }^{3} \mathrm{H}\right]$ phosphoinositides and modlified $\left[{ }^{3} \mathrm{H}\right]$ phosphoinositides on t.l.c.

The phospholipids were isolated from permeabilized thymocytes $\left(3.5 \times 10^{8}\right.$ cells $\left./ \mathrm{ml}\right)$ after $2 \mathrm{~h}$ of incubation with myo-inositol or myo-inositol analogue $(10 \mu \mathrm{Ci} ; 5.5 \mu \mathrm{M})$. The t.l.c. plate was loaded with approx. (a) $1 \%$ of the total phospholipid extract from incubation with myo-[2$\left.{ }^{3} \mathrm{H}\right]$ inositol, (b) $12.5 \%$ of the total phospholipid extract from incubation with 5-deoxy-5-fluoromyo-[2- $\left.{ }^{3} \mathrm{H}\right]$ inositol, (c) $12.5 \%$ of the total phospholipid extract from incubation with 10-3-deoxy3-fluoro-myo- $\left[2{ }^{-3} \mathrm{H}\right]$ inositol or (d) the total phospholipid extract from incubation of 10-6-deoxy6-fluoro-myo-[2- $\left.{ }^{3} \mathrm{H}\right]$ inositol. Phospholipids were extracted and run on t.l.c. as described in the Materials and methods section. The data were displayed with a square-root transformation to allow viewing of low-intensity peaks. The ${ }^{3} \mathrm{H}$ counting efficiency was $0.5 \%$. Products $X$ and $Y$ are discussed in the text.

bound enzyme to free enzyme. Assuming competitive inhibition, the $K_{\mathrm{i}}$ obtained for myo-inositol was $33 \mu \mathrm{M}$ (Figure 3b), similar to the $K_{\mathrm{m}}$ value of $31 \pm 4 \mu \mathrm{M}$ measured by direct incorporation of $m y o-\left[2-{ }^{3} \mathrm{H}\right]$ inositol (Figure 2).

\section{Separation of $\left[{ }^{3} \mathrm{H}\right]$ phosphoinositides and modified [3 $\mathrm{H}]$ phosphoinositides}

The ${ }^{3} \mathrm{H}$-labelled phospholipids formed by incorporation of the three monodeoxyfluoro-myo- $\left[2-{ }^{3} \mathrm{H}\right]$ inositol substrates were separated by t.l.c. on the same plate as standard samples of $\left[{ }^{3} \mathrm{H}\right] \mathrm{PtdIns},\left[{ }^{3} \mathrm{H}\right] \mathrm{PtdIns} 4 P$ and $\left[{ }^{3} \mathrm{H}\right] \mathrm{Ptd} \operatorname{Ins}(4,5) P_{2}$, for direct comparison of their mobilities (Figure 4).

The phospholipid extracts from the three monodeoxyfluoromyo- $\left[{ }^{3} \mathrm{H}\right]$ inositol incubations (5-deoxy-5-fluoro-, 1D-3-deoxy-3fluoro- and 1D-6-deoxy-6-fluoro-myo-[2- $\left.{ }^{3} \mathrm{H}\right]$ inositol) showed the presence of a major product with a mobility slightly greater than that of PtdIns. A hydroxyl group replaced by a fluorine on the inositol ring of PtdIns would be predicted to reduce the polarity 


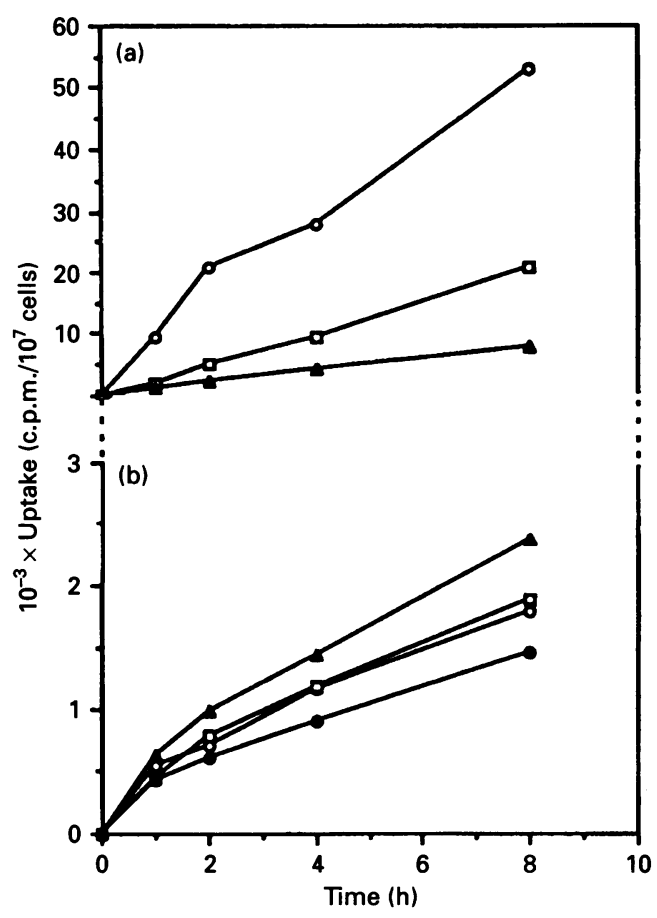

Figure 5 Time course of myo-inositol and monodeoxyfluoro-myo-inositol uptake into intact thymocytes

Aliquots $(220 \mu l)$ of thymocytes $\left(5 \times 10^{7}\right.$ cells $\left./ \mathrm{ml}\right)$ were incubated in the presence of myo-[2${ }^{3} \mathrm{H}$ ]inositol or inositol analogue $(1 \mu \mathrm{Ci} ; 2.5 \mu \mathrm{M})$. Uptake was terminated at the indicated times by removing aliquots $(200 \mu l)$ of the sample and adding them to an ice-cold Ficoll gradient. Centrifugation concentrated the cells at the tip of the Eppendorf tube. ${ }^{3} \mathrm{H}$ and ${ }^{14} \mathrm{C}$ were assayed as described in the Materials and methods section. (a) $\bigcirc$, myo-[2- $\left.{ }^{3} \mathrm{H}\right]$ Inositol; $\square, 2-$ deoxy2-fluoro-myo-[2- $\left.{ }^{3} \mathrm{H}\right]$ inositol; $\mathbf{\Delta}, 10-3-d e o x y-3-f l u o r o-m y o-\left[2-{ }^{3} \mathrm{H}\right]$ inositol. (b) $\mathrm{O}, 10-1-D e o x y-1-$ fluoro-myo-[2- $\left.{ }^{3} \mathrm{H}\right]$ inositol; $\square$, 10-4-deoxy-4-fluoro-myo-[2- $\left.{ }^{3} \mathrm{H}\right]$ inositol; $\boldsymbol{\Delta}, 5$-deoxy-5-fluoromyo-[2- $\left.{ }^{3} \mathrm{H}\right]$ inositol; O, 10-6-deoxy-6-fluoro-myo-[2- $\left.{ }^{3} \mathrm{H}\right]$ inositol.

of the molecule and thus increase its chromatographic mobility in this t.l.c. system. Thus the three monodeoxyfluoro-myo$\left[2-{ }^{3} \mathrm{H}\right]$ inositols were incorporated into phospholipids with the chromatographic properties expected for a phosphatidyl- $n$ deoxy- $n$-fluoro-myo-inositol.

Incubations of permeabilized cells with the three monodeoxyfluoro-myo-[2- $\left.{ }^{3} \mathrm{H}\right]$ inositols all resulted in the formation of a second phospholipid which migrated close to the position of authentic PtdIns4P. However, none of the analogues formed a detectable product with the chromatographic properties expected for a PtdIns $(4,5) P_{2}$ derivative. Minor unidentified components $(\mathrm{X}, \mathrm{Y})$ were detected in the extracts from the 1D-3deoxy-3-fluoro- and 1D-6-deoxy-6-fluoro-myo-[2- $\left.{ }^{3} \mathrm{H}\right]$ inositol incubations which may have this identity, although they had a lower mobility than genuine PtdIns(4,5) $P_{2}$. However, $\mathrm{X}$ and $\mathrm{Y}$ were present at levels of less than $0.1 \%$ of added monodeoxyfluoro-myo- $\left[2-{ }^{3} \mathrm{H}\right]$ inositol, which is below the level at which contaminants could be detected in the radiolabelled analogue preparations (99.9\% purity) (Offer et al., 1992). The minor peaks might therefore result from contaminants.

\section{Uptake of myo-[2- $\left.{ }^{3} \mathrm{H}\right]$ inositol and monodeoxyfluoro-myo- [2- $\left.{ }^{3} \mathrm{H}\right]$ inositol into intact thymocytes}

The time course of $m y o-\left[2-{ }^{3} \mathrm{H}\right]$ inositol uptake into intact thymocytes is shown in Figure 5(a). The uptake of myo-[2${ }^{3} \mathrm{H}$ ]inositol increased approximately linearly with time and had
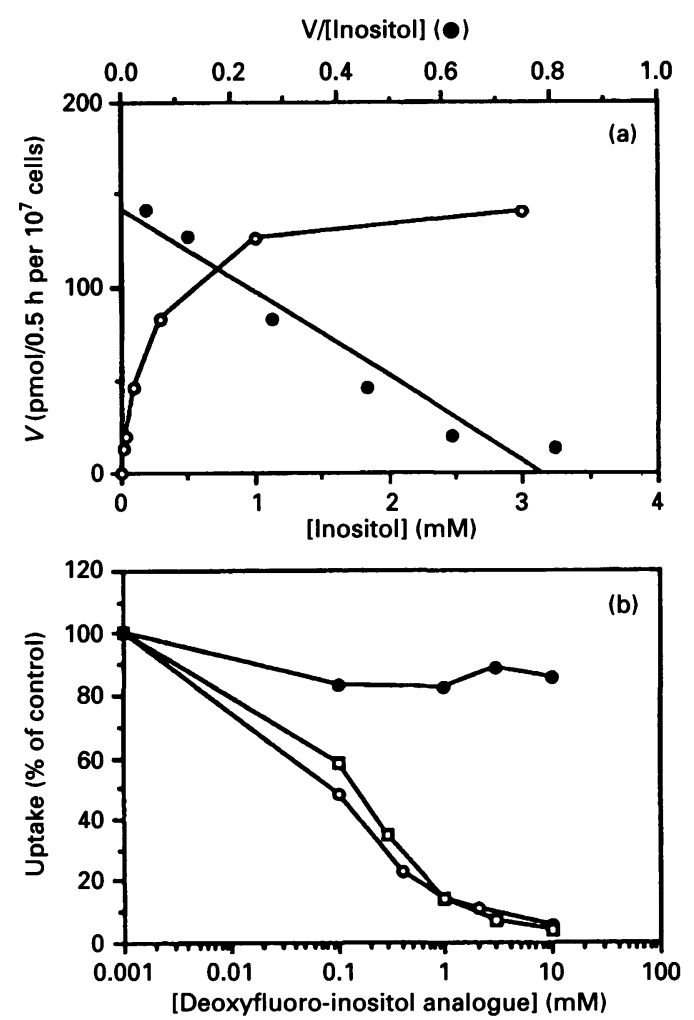

Figure 6 Characterization of myo-inositol uptake into intact thymocytes

Aliquots $(220 \mu l)$ of thymocytes were incubated in the presence of myo- $\left[2{ }^{3} \mathrm{H}\right]$ inositol $(1 \mu \mathrm{Ci})$ at the concentrations indicated. Uptake was terminated $0.5 \mathrm{~h}$ after addition of the myo-[2${ }^{3} \mathrm{H}$ ]inositol by removing aliquots $(200 \mu \mathrm{l})$ of the sample and adding them to an ice-cold Ficoll gradient. Samples were assayed for ${ }^{3} \mathrm{H}$ and ${ }^{14} \mathrm{C}$ as described in the Materials and methods section. Uptake rates $(V)$ were calculated from the ${ }^{3} \mathrm{H}$ associated with the cell pellet and the specific radioactivity in the myo-inositol in each. The data were replotted by the method of Eadie and Hofstee to obtain the apparent $K_{\mathrm{m}}$ of myo-inositol entry. (b) Aliquots $(220 \mu$ ) of thymocytes were incubated in the presence of myo. $\left[2 \cdot{ }^{3} \mathrm{H}\right]$ inositol $(1.0 \mu \mathrm{Ci} ; 2.5 \mu \mathrm{M})$ and monodeoxyfluoromyo-inositol at the concentrations indicated. Samples were taken $0.5 \mathrm{~h}$ after addition of myo$\left[2{ }^{3} \mathrm{H}\right]$ inositol and assayed for ${ }^{3} \mathrm{H}$ and ${ }^{14} \mathrm{C}$. O, 10-1-Deoxy-1-fluoro-myo-inositol and 10-3deoxy-3-fluoro-myo-inositol; $\square$, 2-deoxy-2-fluoro-myo-inositol; O. 5-deoxy-5-fluoro-myoinositol.

not reached equilibrium by $8 \mathrm{~h}$. The intracellular concentration of $m y o-\left[2-{ }^{3} \mathrm{H}\right]$ inositol, calculated from the specific radioactivity of the $m y o-\left[2-{ }^{3} \mathrm{H}\right]$ inositol and assuming a value of $1.2 \times 10^{-13} 1$ for the intracellular volume of murine thymocytes (Brand and Felber, 1984), reached a value of approx. $24 \mu \mathrm{M}$ by $8 \mathrm{~h}$, which is 10 -fold higher than the extracellular concentration of $2.5 \mu \mathrm{M}$. This indicated that uptake of $m y o$-inositol is an active process. The concentration-dependence of myo-inositol uptake was investigated (Figure 6) and was a saturable process with an apparent

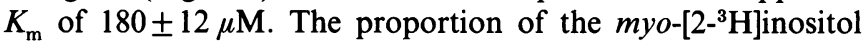
that was incorporated into the phospholipid, estimated in Folch extracts of the cell pellets, was consistently less than $20 \%$ of the total amount of myo- $\left[2-{ }^{3} \mathrm{H}\right]$ inositol taken up into the thymocytes.

The monodeoxyfluoro-myo- $\left[2-{ }^{3} \mathrm{H}\right]$ inositols were incubated with intact thymocytes under the same conditions as for myo$\left[2-{ }^{3} \mathrm{H}\right]$ inositol. The corresponding intracellular concentrations of 2-deoxy-2-fluoro-myo-inositol and 1D-3-deoxy-3-fluoro-myoinositol ( $9.5 \mu \mathrm{M}$ and $4.0 \mu \mathrm{M}$ respectively) were greater than the extracellular concentration of $2.5 \mu \mathrm{M}$ after $8 \mathrm{~h}$, suggesting that uptake of these two compounds was by an active process. The remaining monodeoxyfluoro-myo-inositols were also taken up into intact thymocytes, but their intracellular concentrations had 
not reached the extracellular concentration by $8 \mathrm{~h}$. The uptake rates for these isomers were very similar to that of the sterically modified 2,5-anhydro-myo-inositol (results not shown), indicating that the mechanisms are probably non-specific.

The monodeoxyfluoro-myo-inositols were examined for their ability to inhibit the uptake of myo-inositol into intact cells. 2-Deoxy-2-fluoro-myo-inositol and 1D-3-deoxy-3-fluoro-myoinositol, which were both actively taken up into thymocytes, were also inhibitors of myo-inositol uptake, with half-maximal inhibition at $150 \mu \mathrm{M}$. 1D-1-Deoxy-1-fluoro-myo-inositol was not actively accumulated by thymocytes to the level seen for 1D-3deoxy-3-fluoro-myo-inositol, but was an inhibitor of myo-inositol uptake, showing a similar inhibition curve to its enantiomer (Figure 6b). None of the monodeoxyfluoro-myo-inositols appeared to be pure competitive inhibitors of myo-inositol uptake, as the Dixon plots were hyperbolic. However, this observation was not unexpected, as the process being inhibited is not a simple reaction but is part of a more complex sequence of reactions including action of the PtdIns synthase. 1D-6-Deoxy-6-fluoromyo-inositol and 1D-4-deoxy-4-fluoro-myo-inositol gave halfmaximal inhibition of myo-inositol uptake at a concentration of approx. $10 \mathrm{mM}$ (results not shown), whereas 5-deoxy-5-fluoromyo-inositol showed only slight inhibition of $m y o$-inositol uptake at concentrations up to $10 \mathrm{mM}$.

\section{DiSCUSSION}

\section{Incorporation of myo-[2- $\left.{ }^{3} \mathrm{H}\right]$ inositol into the phosphollpid of electroporated thymocytes}

The specific radioactivity of radiolabelled myo-inositol analogues that was required to analyse phospholipids in studies on intact cells could not be achieved by our labelling procedure. Electroporation has been used by other workers to increase the amount of $m y o-\left[2-{ }^{3} \mathrm{H}\right]$ inositol incorporation into phospholipid (Van Haastert et al., 1988; Authi et al., 1989). We have optimized the conditions of thymocyte cell density $\left(4 \times 10^{8} / \mathrm{ml}\right)$ and $\mathrm{MgATP}^{2-}$ concentration $(12 \mathrm{mM}$ ) to give maximal incorporation of $m y o-\left[2-{ }^{3} \mathrm{H}\right]$ inositol into phospholipid. Increasing the concentration of $\mathrm{MgATP}^{2-}$ to $12 \mathrm{mM}$ increased ${ }^{3} \mathrm{H}$ labelling of all of the phosphoinositides. This allowed the incorporation of the myo-inositol analogues into the phospholipid of the electroporated thymocytes, to be compared with that of myo-inositol over as short a period as possible while the preparation remained at maximal activity. Under these conditions, electroporated thymocytes incorporated over $85 \%$ of the added $m y o-\left[2-{ }^{3} \mathrm{H}\right]-$ inositol (at a total concentration of $2.5 \mu \mathrm{M}$ ) into phospholipid in $2 \mathrm{~h}$. Assuming a value of $9 \mu \mathrm{g}$ of phospholipid $/ 10^{6}$ thymocytes (Moore et al., 1983), myo-inositol was incorporated into $1.0 \mathrm{~mol} \%$ of the total membrane phospholipid. The PtdIns content of thymocyte membranes is approx. $10 \mathrm{~mol} \%$ of total phospholipid (Levis et al., 1976), and therefore approx. 10\% of the total PtdIns was labelled by the myo- $\left[2-{ }^{3} \mathrm{H}\right]$ inositol. The rates of incorporation of myo-inositol and of the inositol analogues into phospholipid were therefore measured under conditions in which a small proportion of the total PtdIns pool was labelled.

There are two mechanisms for myo-inositol incorporation into phospholipids: the de novo synthesis of PtdIns catalysed by PtdIns synthase, and PtdIns/inositol exchange, probably catalysed by the same enzyme (Fischl et al., 1986). It is not possible to distinguish the contribution of either mechanism to $\left[{ }^{3} \mathrm{H}\right]$ PtdIns accumulation from the present data. However, estimates of the phosphatidic acid content of thymocytes as $1 \mathrm{~mol} \%$ of total phospholipid (Moore et al., 1983) were close to the maximum incorporation of myo-inositol obtained. In ad- dition, the MgATP2-dependence of incorporation into Ptdins observed could be explained by increased ATP-dependent synthesis of phosphatidic acid and CTP providing more substrate for PtdIns synthesis and/or CMP removal. Both of these observations are consistent with de novo synthesis. The exchange reaction, by reversal of the synthase, and the $\mathrm{MgATP}^{2-}$ dependence can both be explained in terms of the bisubstrate/biproduct kinetics of the reaction (see below).

The apparent $K_{\mathrm{m}}$ for the incorporation of $m y o$-inositol into the phospholipid of permeabilized thymocytes $(31 \mu \mathrm{M})$ was similar to a previous value of $20-30 \mu \mathrm{M}$ obtained for isolated pig lymphocyte membranes (Moore et al., 1983) and also comparable with the apparent $K_{\mathrm{m}}$ for $m y o$-inositol for the PtdIns synthase of yeast ( $80 \mu \mathrm{M}$; Fischl et al., 1986). The apparent $K_{\mathrm{m}}$ for myoinositol incorporation into the phospholipid of electroporated thymocytes was much lower than the free myo-inositol concentration in thymocytes $(840 \pm 40 \mu \mathrm{M})$, and hence the myoinositol concentration is unlikely to be limiting for myo-inositol incorporation into PtdIns in vivo. The $K_{\mathrm{m}}$ was much lower than many of the published values of the apparent $K_{\mathrm{m}}$ for myo-inositol of PtdIns synthase from various tissues, including rat liver (2.5 mM; Takenawa and Egawa, 1980), dog pancreas (0.76 mM; Ghalayini and Eichberg, 1985) and turkey erythrocyte membranes (0.3 mM; McPhee et al., 1991a). These differences in the apparent $K_{\mathrm{m}}$ for myo-inositol incorporation into PtdIns may arise because PtdIns synthesis is a membrane-associated bisubstrate reaction, and in most studies the state of the CDPdiacylglycerol pool was not established. The size of this pool is important because a bisubstrate $(A+B)$ reaction has two possible pathways, via the complexes enz*A or enz*B, and the $K_{\mathrm{m}}$ of $\mathrm{A}$ will be different for enz and enz*B (Laidler and Bunting, 1973, and references therein).

\section{Incorporation of monodeoxyfiuoro-myo-inositols into the phospholipid of electroporated thymocytes}

None of the three monodeoxyfluoro-myo-inositols (5-deoxy-5fluoro-myo-inositol, 1D-3-deoxy-3-fluoro-myo-inositol and 1D-6deoxy-6-fluoro-myo-inositol) that were incorporated into phospholipid were as good substrates for the PtdIns synthase as was myo-inositol. 5-Deoxy-5-fluoro-myo-inositol and 1D-3deoxy-3-fluoro-myo-inositol were both incorporated into phospholipid to approx. $10 \%$ of the amount of myo-[2${ }^{3} \mathrm{H}$ ]inositol incorporation after $1 \mathrm{~h}$, whereas 1D-6-deoxy-6-fluoromyo-inositol was poorly incorporated, to approx. $0.5 \%$ of the incorporation of myo-inositol.

The apparent $K_{1}$ values of the monodeoxyfluoro-myo-inositols as competitive inhibitors of myo-inositol incorporation were very similar to their $K_{\mathrm{m}} \mathrm{s}$ for incorporation into phospholipid. 1DDeoxy-1-fluoro-myo-inositol, 2-deoxy-2-fluoro-myo-inositol and 1D-4-deoxy-4-fluoro-myo-inositol were neither incorporated into phospholipid nor acted as inhibitors. 1D-1-Deoxy-1-fluoro-myoinositol would not be predicted to be incorporated, as the 1Dposition is the site of attachment of the phosphatidyl group.

These results confirm previous reports of the high selectivity of the PtdIns synthase of mammalian systems for myo-inositol compared with various inositol analogues (Paulus and Kennedy, 1960; Benjamins and Agranoff, 1969; Moyer et al., 1988a,b). The results presented here for the incorporation of the monodeoxyfluoro-myo-inositols into the phospholipid of thymocytes are consistent with those obtained by Moyer et al. $(1988 \mathrm{a}, \mathrm{b})$ for the incorporation of myo-inositol analogues into phospholipid of L1210 cells, and also show that 1D-3-deoxy-3fluoro-myo-inositol (unavailable to Moyer and co-workers) and 1D-6-deoxy-6-fluoro-myo-inositol (which was available only as a 
racemate; Moyer et al., 1988b) were both incorporated into phospholipid. Somewhat different results have been reported for the inhibitor and substrate behaviour of deoxyfluoroinositols towards turkey erythrocyte membranes (McPhee et al., 1991b).

\section{Characterization of monodeoxyfluoro-myo-[2-'H] Inositol incorporation Into phosphoinositides}

The ratio of ${ }^{3} \mathrm{H}$-labelled polyphosphoinositide to PtdIns in the electroporated system was much higher than in intact thymocytes (Taylor et al., 1984), presumably as a result of the high concentration of $\mathrm{MgATP}^{2-}$ used. The cellular controls of PtdIns phosphorylation are not known. The exchange of the 4- and 5phosphates with ATP is a rapid process, and the control may be by chemical and/or surface electrical potential. This is consistent with the shift of the equilibrium to the polyphosphoinositide products in the presence of bivalent ions that bind to polyphosphoinositides. Alternatively, the difference in levels may also arise from the presence of more than one pool of PtdIns.

Incubations of electroporated thymocytes with 5-deoxy-5fluoro-myo-inositol produced two products in positions predicted for the chromatographic properties of fluorine-substituted forms of PtdIns and PtdIns4P. The 5-position was substituted by fluorine and unable to form a modified $\operatorname{PtdIns}(4,5) P_{2}$. These data are consistent with previous work on 5-deoxy-5-fluoro-myoinositol, which showed that intact L1210 cells incubated with this analogue were capable of synthesizing these two modified lipids (Moyer et al., 1988a). The phospholipid extract from the incubation of 1D-3-deoxy-3-fluoro-myo-[2- $\left.{ }^{3} \mathrm{H}\right]$ inositol showed a major peak with the chromatographic properties of a fluorinesubstituted PtdIns. A second peak corresponding to a substituted PtdIns4 $P$ was also observed, but in much smaller quantities than in the lipid obtained with the 5-deoxy-5-fluoro-myo- $\left[2-{ }^{3} \mathrm{H}\right]$ inositol incubation to which it is comparable. There was no significant peak present with chromatographic properties similar to those of PtdIns $(4,5) P_{2}$, possibly because of the small amount of substituted PtdIns4P (phosphatidyl-3-deoxy-3-fluoro-myoinositol 4-phosphate) present as substrate. Incubation with 1D-6deoxy-6-fluoro-myo-[2- $\left.{ }^{3} \mathrm{H}\right]$ inositol would be predicted to form substituted analogues of PtdIns, PtdIns4P and PtdIns $(4,5) P_{2}$, because the fluorinated position is not the site of attachment of a phosphate. However, only two significant peaks were detected, corresponding to modified PtdIns and PtdIns $4 P$.

\section{Entry of myo-inositol and monodeoxyfluoro-myo-inositols into intact thymocytes}

The uptake of myo-inositol into intact thymocytes was a saturable process with an apparent $K_{\mathrm{m}}$ for myo-inositol of $180 \mu \mathrm{M}$. All of the monodeoxyfluoro-myo- $\left[2-{ }^{3} \mathrm{H}\right]$ inositols entered intact thymocytes, but only 2-deoxy-2-fluoro-myo-inositol and 1D-3deoxy-3-fluoro-myo-inositol showed uptake where the intracellular concentration exceeded the extracellular concentration.

There was some correlation between the uptake of the analogues into cells and their ability to inhibit myo-inositol uptake into the cells. For example, the actively accumulated analogues 2-deoxy-2-fluoro-myo-inositol and 1D-3-deoxy-3fluoro-myo-inositol gave half-maximal inhibition of myo-inositol uptake at $150 \mu \mathrm{M}$. Unexpectedly, 1D-1-deoxy-1-fluoro-myoinositol, which was not taken up actively into thymocytes, gave quantitatively similar inhibition to its enantiomer, 1D-3-deoxy-3fluoro-myo-inositol. Dixon plots for the inhibition of myoinositol uptake by 2-deoxy-2-fluoro-myo-inositol, 1D-1-deoxy1-fluoro-myo-inositol and 1D-3-deoxy-3-fluoro-myo-inositol did not show simple competition. Although myo-inositol uptake was inhibited by approx. $50 \%$ at $150 \mu \mathrm{M}$ of all three compounds, significant uptake of myo-inositol occurred when each of the inhibitors was used at a concentration of $10 \mathrm{mM}$. This residual uptake may be due to the synthesis of phospholipid, which accounts for up to $20 \%$ of the cellular uptake under normal conditions, and probably more when uptake is inhibited.

Both enantiomers of 4-deoxy-4-fluoro-myo-inositol showed similar uptake into thymocytes and were weak inhibitors of myoinositol uptake. 5-Deoxy-5-fluoro-myo-inositol entered thymocytes by a non-concentrative mechanism, but was not taken up by the active transport system which exists in these cells. In addition, $m y o$-inositol uptake was only inhibited slightly by 5deoxy-5-fluoro-myo-inositol in thymocytes. Auchus et al. (1985) were unable to demonstrate any uptake of labelled 5-deoxy-myoinositol into their cell line, which possessed an active uptake process for myo-inositol. In contrast, Moyer et al. (1988a) observed uptake of both 5-deoxy-myo-[5- $\left.{ }^{3} \mathrm{H}\right]$ inositol and 5deoxy-5-fluoro-myo- $\left[{ }^{3} \mathrm{H}\right]$ inositol into L1210 cells. In these L1210 cells, myo-inositol uptake occurred by a passive mechanism.

\section{The monodeoxyfluoro-myo-inositols as potential inhibitors of Ptdins $(4,5) \boldsymbol{P}_{2}$-mediated responses}

For the monodeoxyfluoro analogues to act as potential inhibitors of cell growth in intact cells, they must first be taken up into the cells, and our data indicate that only 2-deoxy-2-fluoro-myoinositol and 1D-3-deoxy-3-fluoro-myo-inositol were actively taken up into the cells. Only three of the monodeoxyfluoro-myoinositols (1D-3-deoxy-3-fluoro-myo-inositol, 5-deoxy-5-fluoromyo-inositol and 1D-6-deoxy-6-fluoro-myo-inositol) showed activity as substrates for the synthase. The 6-substituted analogue possessed very low substrate activity. Only the 1D-3-deoxy3-fluoro-myo-inositol analogue was both taken up actively into thymocytes and incorporated into phospholipid. The overall selectivity for myo-inositol displayed by the uptake and PtdIns synthase system makes it unlikely that the monodeoxyfluoromyo-inositols will show any activity as inhibitors of PtdIns $(4,5) P_{2}$ formation or breakdown in intact cells. However, the development of cell-permeable derivatives or the use of methods to bypass the uptake mechanism, such as micro-injection, could make these analogues useful probes in the study of phosphoinositide responses and cell growth. In addition, they will be useful for the study of phosphoinositide metabolism in cell-free systems and as tools for the study of myo-inositol uptake.

We thank Dr. H. P. Voorheis (Department of Biochemistry, Trinity College, Dublin, Ireland) for contributing ideas, and Dr. S. D. Clarke for preparing some of the monodeoxyfluoro-myo-inositols. This work was supported by a project grant from the Medical Research Council to J.C.M. J.L. 0. held a Science and Engineering Research Council Studentship.

\section{REFERENCES}

Alcover, A., Alberini, C., Acuto, 0., Clayton, L. K., Transy, C., Spagnoli, G. C., Moingeon, P., Lopez, P. and Reinherz, E. L. (1988) EMBO J. 7, 1973-1977

Auchus, R. J., Wilson, D. B., Covey, D. F. and Majerus, P. W. (1985) Biochem. Biophys.

Res. Commun. 130, 1139-1146

Authi, K. S., Hughes, K. and Crawford, N. (1989) FEBS Lett. 254, 52-58

Benjamins, J. A. and Agranoff, B. W. (1969) J. Neurochem. 16, 513-527

Brand, M. D. and Felber, F. M. (1984) Biochem. J. 224, 1027-1030

Desai, D. M., Newton, M. E., Kadlecek, T. and Weiss, A. (1990) Nature (London) 348,

66-69

Fischl, A. S., Homann, M. J., Poole, M. A. and Carman, G. M. (1986) J. Biol. Chem. 261 3178-3183

Ghalayini, A. and Eichberg, J. (1985) J. Neurochem. 44, 175-182

Laidler, K. J. and Bunting, P. S. (1973) The Chemical Kinetics of Enzyme Action pp. 114-118, Clarendon Press, Oxford

Levis, G. M., Evangelatos, G. P. and Crumpton, M. J. (1976) Biochem. J. 156, 103-110. 
Maslanski, J. A. and Busa, W. B. (1990) In Methods in Inositide Research (Irvine, R. F., ed.), pp. 113-126, Raven Press, New York

McPhee, F., Lowe, G., Vazin, C. and Downes, C. P. (1991a) Biochem. J. 275, 187-192

McPhee, F., Downes, C. P. and Lowe, G. (1991b) Biochem. J. 277, 407-412

Moore, J. P., Smith, G. A., Hesketh, T. R. and Metcalfe, J. C. (1983) Biochem. J. 212 691-697

Moyer, J. D., Reizes, 0., Ahir, S., Jiang, C., Malinowski, N. and Baker, D. C. (1988a) Mol. Pharmacol. 33, 683-689

Moyer, J. D., Malinowski, N., Napier, E. A. and Strong. J. (1988b) Biochem. J. 254 95-100

Offer, J. L., Voorheis, H. P., Metcalfe, J. C. and Smith, G. A. (1992) J. Chem. Soc. Perkin Trans. 1, 953-960
Paulus, H. and Kennedy, E. P. (1960) J. Biol. Chem. 235, 1303-1311

Stanley, P. E. and Williams, S. G. (1969) Anal. Biochem. 29, 381-392

Stein, J. M. and Smith, G. A. (1982) Techniques in the Life Sciences, vol. B4/1, Elsevier/North-Holland Publishing Company, Amsterdam

Sussman, J. J., Bonifacino, J. S., Lipponcott-Schwartz, J., Weissman, A. M., Saito, T., Klausner, R. D. and Ashwell, J. D. (1988) Cell 52, 85-95

Takenawa, T. and Egawa, K. (1980) Arch. Biochem. Biophys. 202, 601-607

Taylor, M. V., Metcalfe, J. C., Hesketh, T. R., Smith, G. A. and Moore, J. P. (1984) Nature (London) 312, 462-465

Van Haastert, P. J. M., De Vries, M. J., Penning, L. C., Roovers, E., Van der Kaay, J., Erneux, C. and Van Lookeren Campagne, M. M. (1988) Biochem. J. 258, 571-586 Whitman, M. and Cantley, L. (1988) Biochim. Biophys. Acta 948, 327-344

Received 9 September 1992/19 November 1992; accepted 3 December 1992 